\title{
Operating Profit and Net Profit: Measurements of Profitability
}

\author{
Anuruddika K. K. R. Jayathilaka \\ University of Sri Jayewardenepuna, Gangodawila, Nugegoda, Sri Lanka \\ Email: anuruddikadec26@gmail.com
}

How to cite this paper: Jayathilaka, A.K.K.R. (2020) Operating Profit and Net Profit: Measurements of Profitability. Open Access Library Journal, 7: e7011. https://doi.org/10.4236/oalib.1107011

Received: November 17, 2020

Accepted: December 13, 2020

Published: December 16, 2020

Copyright $\odot 2020$ by author(s) and Open Access Library Inc.

This work is licensed under the Creative Commons Attribution International License (CC BY 4.0).

http://creativecommons.org/licenses/by/4.0/

\section{(c) (i) Open Access}

\begin{abstract}
This paper begins by describing the main concepts which the research problem of this study is derived. This description of operating profit then leads onto an empirical review, with a view of discovering areas of existing literature that are focusing on evaluating the phenomena in concern. Accordingly, the chapter begins with an explanation of the operating profits and from here the chapter moves on to describe the net profit in organizations. It addresses what the net profit is. How the net profit is calculated also described drawing on existing literature. This discussion on context then leads to the components of net profit. Here it attempts to identify the relationship between operating profit and net profit for the year. As such they are drawn out as the main themes around which the paper builds its framework.
\end{abstract}

\section{Subject Areas}

Accounting

\section{Keywords}

Profitability Measurements, Operating Profits, Earnings before Interests and Taxes, Net Profits, Net Income, Total Comprehensive Income, Net Earnings, Net Profit, Bottom Line

\section{Introduction}

\subsection{Background of the Study}

At present where the organizations are operating in order to survive in a dynamic and unstable environment, they are highly focusing on their profits. Even the quality and efficiency of managers depend on their ability to identify the elements that can lead to increased profitability (Alarussi \& Alhaderi, 2018) [1]. In general, profitability is defined as the earnings of a company that are gener- 
ated from revenue after deducting all expenses incurred during a given period (Alarussi \& Alhaderi, 2018) [1]. According to Bekmezci (2015), it is one of the most important factors that are signal management's success, shareholders' satisfaction, attraction for investors and the company's sustainability (Alarussi \& Alhaderi, 2018) [1]. Undoubtedly, the ultimate goal of any firm is to maximize the wealth of its shareholders by increasing the value of its stocks (Alarussi \& Alhaderi, 2018) [1]. Thus, it is important to have an insight in measurements of profitability. From all the measurements since operating profit and net profit are the commonly used measurements, it is aimed to find what they are and the relationship between them.

\subsection{The Research Problem/Research Question}

"What is the relationship between operating profit and net profit for the year?" is the research question that the author is focusing on throughout the study. The paper aims: firstly, to understand what the operating profit and net profit are using the existing literature, finally to explore the relationship between operating profit and net profit for the year.

\section{Methodology}

In order to achieve the above-mentioned research objectives of the study, a comprehensive literature survey was conducted incorporating desk research strategy in addition to the rational thinking of the author and observations. A countless of literature related to theory and practices of Operating Profit and Net Profit is available in various publications and conferences. The author searched for the articles related to Operating Profit and Net Profit using the search criteria, the author has used the five main terms related to Operating Profit and Net Profit: "Profitability measurements", "Operating profits", "Earnings Before Interests and Taxes", "Net profits", "Net Income". The search criteria were decided in a way where the research topic is covered or addressed.

\section{Literature Review}

\subsection{Operating Profit}

In general, operating profit is also known as Earnings Before Interests and Taxes (EBIT). In other words, the profit calculated by excluding the interest expenses incurred for financing and the taxes paid to the government. In order to calculate operating profit, only operating expenses, which are the expense a business incurs through its normal business operations, are subtracted from gross profit. Thus, the mainly when evaluating the operating profits, the literature review will be woven around gross profit, operating expenses and finally operating profit.

Many merchandisers are juggling inventories in response to the forces affecting product pricing, cost of goods sold, volumes, and shifting product mix (Edwards, 2016) [2]. That is, gross profits are needed to support operating expenses, income taxes, and net earnings (Edwards, 2016) [2]. In some businesses, the 
right combination of prices, product costs, and availabilities at the right moment is becoming ever more elusive (Edwards, 2016) [2]. This usually results in under- or overstocking; thereby, creating unrecoverable costs and/or lost opportunity costs that erode earnings (Edwards, 2016) [2]. Practitioners in recent years have devoted increasing attention to gross profit as a signal of future profitability, particularly for firms whose expansion activities temporarily depress earnings (Chiu \& Haight, 2014) [3]. Given the potential for gross profit surprises to provide information about future profitability that may not be fully captured by bottom-line earnings surprises, we are naturally interested in testing whether investors incorporate such information into stock prices in a complete and timely manner (Chiu \& Haight, 2014) [3]. As gross profit purges earnings of nonrecurring items (e.g., special items) and recurring items that may not persist at their current levels (e.g., advertising expense to increase product awareness), future returns stemming from earnings surprises are likely to capture a sizeable component related to information in gross profit surprises (Chiu \& Haight, 2014) [3]. Furthermore, the matching of cost of sales to revenues (as captured by gross profit) likely provides a more reliable signal about the sustainability of earnings growth relative to the signal provided by revenue in isolation since the matching process implicitly reveals the maximum potential "return" on sales to investors (Chiu \& Haight, 2014) [3].

Also, the operating expenses are usually abbreviated as OPEX. Operating expenses are typically a major business expenditure and are generally allocated to different divisions in proportion to the business revenues (Cepeda, 2002) [4]. Allocation of the operating expenses is a significant challenge since such an allocation must be done fairly and equitably to evaluate the performance of the business division objectively (Cepeda, 2002) [4]. A Cost Allocation Management System (CAMS) allocates operating expenses to the deal activity for a business entity (Cepeda, 2002) [4] was introduced as a solution for the above problem. This is due to the understood value of the operating expenses. Regarding the operating expenses, the total cost can be separated into operating cost and other expenses (including taxes, depreciation etc.) (Said \& Tumin, 2011) [5]. Arbitrary allocation also occurs in the calculation of operating expenses both in selling and marketing expenses and in general and administrative expenses (Dermawan \& Indrajathi, 2017) [6]. Related to the immediate recognition as advertising expenses and research \& development expenses also affect the quality of earnings (Dermawan \& Indrajathi, 2017) [6]. The influence of operating expenses... has resulted as significant in 9 years and 7 years, respectively during 10 years period between 1991-92 and 2000-01 (Bodla \& Verma, 2006) [7], which justifies my argument made above as it is a valuable variable. In the same article of "Determinants of Profitability of Banks in India: A Multivariate Analysis", Operating Expenses is another variable found having negative impact on profitability of banks in India (Bodla \& Verma, 2006) [7]. Operating Expenses comprise, among other wages expenses and non-wages expenses such as rent, taxes and lighting, adver- 
tisement, directors fees and allowances and legal charges (Bodla \& Verma, 2006) [7]. The term "operating expenses" when used includes general expenses and commissions for the ordinary line of business, excluded are taxes, expenses of investment operations and benefit payments (Pritchett, 1973) [8].

As every definition found in the literature there is always the term of taxes. Hereinafter, the literature review is all about the "tax" as defined in literature available. In "Global organizations and taxes: An analysis of the dividend, interest, royalty, and management fee payments between U.S. multinationals' foreign affiliates" examine the effects of taxes on cross-border dividend, interest, royalty, and management fee payments (Collins \& Shackelford, 1997) [9]. Through that, they have examined how taxes affect the location of the supplier and the terms of the contracts for the provision of equity and intangible capital within the worldwide organization (Collins \& Shackelford, 1997) [9]. The concept of "tax expenditures" holds that certain provisions of the tax laws are not really tax provisions, but are actually government spending programs disguised in tax language (Thuronyi, 1988) [10]. In some cases, repealed tax expenditures could be replaced by direct subsidy programs that would furnish government assistance more effectively, while in other cases, federal assistance could be eliminated entirely (Thuronyi, 1988) [10]. Surrey defines tax expenditures as departures from a "normative income tax," and his normative tax starts with the Haig-Simons definition of income (or "economic income"): an individual's consumption plus the change in her net worth over a given period (Thuronyi, 1988) [10]. These are the evidences that taxes are inevitable, only will be zero if there will be a zero income, and that taxes should be taken into consideration in decision making and evaluating the financial statement.

Interest expense relates to the cost of borrowing money (Wikimedia Foundation, 2020) [11]. It is the price that a lender charges a borrower for the use of the lender's money (Wikimedia Foundation, 2020) [11]. On the income statement, interest expense can represent the cost of borrowing money from banks, bond investors, and other sources (Wikimedia Foundation, 2020) [11]. Also, the same can be defined as, interest expense is a non-operating expense shown on the income statement which represents interest payable on any borrowings - bonds, loans, convertible debt or lines of credit (Kagan, Investopedia, 2020) [12]. It is essentially calculated as the interest rate times the outstanding principal amount of the debt (Kagan, Investopedia, 2020) [12]. An interest expense is an accounting item that is incurred due to servicing debt. Interest expenses are often given favorable tax treatment (Kagan, Investopedia, 2020) [12]. For companies, the greater the interest expense the greater the potential impact on profitability. Coverage ratios can be used to dig deeper (Kagan, Investopedia, 2020) [12].

Operating profit is highly used by the managers in decision making as it reflects the revenue and expenses that they can control. The company's performance can be seen from the operating profit (OP) (Dermawan \& Indrajathi, 2017) [6]. Edwards and Bell [1961], and many others after them, have advocated 
a breakdown of current value income into two main components: current operating profit (defined as the excess of current revenue over the current replacement cost of services used in producing the revenue) and the remainder, realizable holding gain (or realizable cost savings) (Prakash \& Sunder, 1979) [13]. This indicates the value of calculating of operating profit when evaluating a business organization. The business profit concept requires that operating profit be carefully distinguished from gains resulting from holding activities [Edwards and Bell, 1961, p. 226] (Prakash \& Sunder, 1979) [13]. However, if, for speculative reasons, labor costs are incurred earlier or later than what is dictated by operating considerations, the related holding gains should also be excluded from the operating profits (Prakash \& Sunder, 1979) [13]. The optimal operating profit increases with the reserve capacity until the latter exceeds a certain value (Cao, Liu, Koh, \& Smith, 2020) [14]. Operating profit takes the profitability metric a step farther to include all operating expenses, including those included in the gross profit calculation (Kagan, Investopedia, 2020) [12]. As a result, operating profit is all of the profit generated except for interest on debt, taxes, and any one-off items, such as a sale of an asset (Kagan, Investopedia, 2020) [12]. This is why operating income is also referred to as earnings before interest and taxes (EBIT) (Kagan, Investopedia, 2020) [12]. Operating profit represents the earnings power of a company with regard to revenues generated from ongoing operations (Kagan, Investopedia, 2020) [12].

\subsection{Net Profit}

In business and accounting, net income (also total comprehensive income, net earnings, net profit, bottom line, sales profit, or credit sales) is an entity's income minus cost of goods sold, expenses, depreciation and amortization, interest, and taxes for an accounting period (Wikimedia Foundation, 2020) [15]. Net income, also called net profit, reflects the amount of revenue that remains after accounting for all expenses and income in a period (Kagan, Investopedia, 2020) [12]. Net income is the last line and sits at the bottom of the income statement (Kagan, Investopedia, 2020) [12]. As a result, it's often referred to as a company's "bottom line" number. Net profitability is an important indicator for ecommerce and retail businesses to measure, since increases in revenue don't always translate to increased profitability (Glew, n.d.) [16]. Net profit tells you your true bottom line, how much money you're actually left with at the end of the day (Glew, n.d.) [16].

Net income can be distributed among holders of common stock as a dividend or held by the firm as an addition to retained earnings (Wikimedia Foundation, 2020) [15]. As profit and earnings are used synonymously for income (also depending on UK and US usage), net earnings and net profit are commonly found as synonyms for net income (Wikimedia Foundation, 2020) [15]. Often, the term income is substituted for net income, yet this is not preferred due to the possible ambiguity (Wikimedia Foundation, 2020) [15]. Net income is infor- 
mally called the bottom line because it is typically found on the last line of a company's income statement (a related term is top line, meaning revenue, which forms the first line of the account statement) (Wikimedia Foundation, 2020) [15]. In simplistic terms, net profit is the money left over after paying all the expenses of an endeavor (Wikimedia Foundation, 2020) [15]. In practice this can get very complex in large organizations (Wikimedia Foundation, 2020) [15]. The bookkeeper or accountant must itemize and allocate revenues and expenses properly to the specific working scope and context in which the term is applied. Net income is usually calculated per annum, for each fiscal year (Wikimedia Foundation, 2020) [15]. The items deducted will typically include tax expense, financing expense (interest expense), and minority interest (Wikimedia Foundation, 2020) [15]. Likewise, preferred stock dividends will be subtracted too, though they are not an expense (Wikimedia Foundation, 2020) [15]. Net income can also be calculated by adding a company's operating income to non-operating income and then subtracting off taxes (Wikimedia Foundation, 2020) [15]. The net profit margin percentage is a related ratio where this figure is calculated by dividing net profit by revenue or turnover, and it represents profitability, as a percentage (Wikimedia Foundation, 2020) [15].

Here let us review how some different organizations are recording net profits as few examples. Merchandising is one of the most common businesses. We recognize the profit at the time when selling, is performed (Myers, 1959) [17]. Two reasons commonly are given for recognizing profit at this time: 1) an asset has been transferred for a valid claim (transfer); 2) the merchant's opinion as to value is not needed (objectivity) (Myers, 1959) [17]. A manufacturer's business is much like that of a merchant except that an extra step is added, converting the purchased raw materials into salable units (Myers, 1959) [17]. This gives an extra point at which profit might be recognized, i.e. time of efficient manufacture (Myers, 1959) [17]. Profit is recognized by magazine publishers in the period when the magazines are distributed (Myers, 1959) [17]. In most cases sale occurs and cash is received at the time the subscription is booked (Myers, 1959) [17]. Lending agencies (banks, small loan companies, etc.) generally recognize profit over the period a loan is outstanding (Myers, 1959) [17]. When the note is discounted at the inception of the loan, the banker has, in a sense, collected the fee in advance (Myers, 1959) [17]. A company owning and renting real estate presents an interesting case (Myers, 1959) [17]. Typically, rents are taken into income in the period to which the rent applies. Expenses are recognized as incurred (Myers, 1959) [17]. A major function of such a firm is providing various building services through payment of taxes, insurance, and the costs of maintenance, heat, and elevator operation (Myers, 1959) [17]. It is suggested by Myers (1959) that there is a need to give special attention to the development of a single theory for the timing of profit recognition.

The calculation itself for net profit is fairly simple, it's just gathering all the data you need that can be tricky (Glew, n.d.) [16]. Since net profit equals total 
revenue after expenses, to calculate net profit, you just take your total revenue for a period of time and subtract your total expenses from that same time period (Glew, n.d.) [16]. Net income is the result of all costs, including interest expense for outstanding debt, taxes, and any one-off items, such as the sale of an asset or division (Kagan, Investopedia, 2020) [12]. Net income is important because it shows a company's profit for the period when taking into account all aspects of the business (Kagan, Investopedia, 2020) [12]. In other words, net income includes revenue, COGS, overhead expenses and operating expenses, operating profit, debt costs, taxes, and any other financial line item that adds or subtracts to the income of the company (Kagan, Investopedia, 2020) [12]. Investors may often hear or read net income described as earnings, which are synonymous with each other (Kagan, Investopedia, 2020) [12]. In order to improve net profits, Grew (n.d.) suggests Review pricing, Remove unprofitable products and services, Control inventory, Reduce overhead, and Reduce overall direct costs. In another way in literature in calculating the net profit is stated as below as defined by Farris, Paul W.; Neil T. Bendle; Phillip E. Pfeifer; David J. Reibstein (2010) (Wikimedia Foundation, 2020) [15].

Net profit is a measure of the fundamental profitability of the venture. "It is the revenues of the activity less the costs of the activity. The main complication is... when needs to be allocated" across ventures. "Almost by definition, overheads are costs that cannot be directly tied to any specific" project, product, or division. "The classic example would be the cost of headquarters staff." "Although it is theoretically possible to calculate profits for any sub-(venture), such as a product or region, often the calculations are rendered suspect by the need to allocate overhead costs." Because overhead costs generally don't come in neat packages, their allocation across ventures is not an exact science.

\subsection{Relationship between Operating Profit and Net Profit for the Year}

Expenses that factor into the calculation of net income but not operating profit include payments on debts, interest on loans, and one-time payments for unusual events such as lawsuits (Kagan, Investopedia, 2020) [12]. When it comes to the payments of debts, the principal payment is recorded as a reduction of the liability Notes Payable or Loans Payable, while, the interest on the loan will be reported as expense on the income statement in the periods when the interest is incurred (Averkamp, 2020) [18]. Whilst the interest expense is a non-operating expense shown on the income statement (Kagan, Investopedia, 2020) [12]. It represents interest payable on any borrowings - bonds, loans, convertible debt or lines of credit (Kagan, Investopedia, 2020) [12]. It is essentially calculated as the interest rate times the outstanding principal amount of the debt (Kagan, Investopedia, 2020) [12]. A one-time item is a gain, loss, or expense on the income statement that is nonrecurring in nature and therefore not considered part of a company's ongoing business operations (Kenton, 2020) [19]. To get an accurate 
gauge of a company's operating performance, one-time items are usually excluded by analysts and investors while evaluating a company (Kenton, 2020) [19]. Although many one-time items hurt earnings or profit, there are one-time items that add to earnings in the reporting period (Kenton, 2020) [19]. One-time items listed on a company's financial statements may include: Restructuring charges, such as when a company modifies its debt structure, Asset impairment or write-off, which is a charge that occurs when the market value of an asset is lower than the asset's value listed on the balance sheet, Loss from discontinued operations, which is from an operation being shut down, Loss from early retirement of debt, such as a company paying off its debt-or bonds-early, M\&A or divestiture-related costs, which can result from mergers and acquisitions, Gain or loss from an asset sale, such as the sale of equipment, Extraordinary legal costs, Natural disaster damage costs, Charge stemming from a change in accounting policy etc. (Kenton, 2020) [19].

Additional income not counted as revenue is also considered in the calculation of net income and includes interest earned on investments and funds from the sale of assets not associated with primary operations (Kagan, Investopedia, 2020) [12]. Revenue is the total amount of income generated by the sale of goods or services related to the company's primary operations (Boyte-White, 2020) [20]. Revenue, also known as gross sales, is often referred to as the "top line" because it sits at the top of the income statement (Boyte-White, 2020) [21]. Income, or net income, is a company's total earnings or profit (Boyte-White, 2020) [21]. When investors and analysts speak of a company's income, they're actually referring to net income or the profit for the company (Boyte-White, 2020) [21]. Non-Operating Revenue and Gains are the other income in a company. Revenues realized through secondary, non-core business activities are often referred to as non-operating recurring revenues (Chen, 2020) [20]. These revenues are sourced from the earnings which are outside of the purchase and sale of goods and services and may include income from interest earned on business capital lying in the bank, rental income from business property, income from strategic partnerships like royalty payment receipts or income from an advertisement display placed on business property (Chen, 2020) [20]. Also called other income, gains indicate the net money made from other activities, like the sale of long-term assets (Chen, 2020) [20]. These include the net income realized from one-time non-business activities, like a company selling its old transportation van, unused land, or a subsidiary company (Chen, 2020) [20]. Revenue should not be confused with receipts (Chen, 2020) [20]. Revenue is usually accounted for in the period when sales are made or services are delivered. Receipts are the cash received and are accounted for when the money is actually received (Chen, 2020) [20].

It's important to note that a company can generate a positive number for operating profit but have a loss or report negative net income for the quarter or fiscal year (Kagan, Investopedia, 2020) [12]. If, for example, a company gene- 
rates $\$ 100$ million in operating profit, but the company has a significant amount of debt on its balance sheet, the interest expense would be deducted from operating profit to calculate net income (Kagan, Investopedia, 2020) [12]. If the interest expense was $\$ 110$ million for the period, the company would record a $\$ 10$ million loss in net income despite producing $\$ 100$ million in operating profit (Kagan, Investopedia, 2020) [12]. As a result, all profitability metrics on an income statement should be analyzed, including gross profit, operating profit, and net income to determine where a company is earning its profits or where its losing money (Kagan, Investopedia, 2020) [12]. Profitability metrics address questions about a company's financial performance and financial position such as these: Is the company profitable? Does it make good use of assets, equities, and debt? Is it producing value for shareholders? Will the company survive and grow? (Schmidt, 2020) [22]. Business textbooks typically describe the highest-level objective for profit-making companies as "Increasing owner value" (Schmidt, 2020) [22]. Firms pursue this objective by earning profits (Schmidt, 2020) [22]. After a successful period, they can use earnings to increase owner value in two ways: firstly, by paying dividends directly to shareholders, secondly, by adding the remaining profits to an equity item on the Balance sheet, Retained earnings (Schmidt, 2020) [22]. In this sense, earning profits is a company's reason for being and, this means that profitability metrics measure the firm's ability to reach its highest-level objectives (Schmidt, 2020) [22]. As a result, analysts compare the firm's current Operating margin, for instance, to other companies, industry standards, or the firm's margins in previous periods (Schmidt, 2020) [22].

\section{Conclusion}

In summary, this paper on literature explained operating profit, net profit and relationship between operating profit and net profit for the year by reviewing existing literature with a view of gathering insights. While both operating profit and net income are measurements of profitability, operating profit is just one of many calculations that occur along the way from total revenue to net income (Kagan, 2020) [12]. The relationship was assessed because these two measures of profitability are the most simple but important calculations made in the companies where the profit is their motivational factor.

\section{Conflicts of Interest}

The author declares no conflicts of interest regarding the publication of this paper.

\section{References}

[1] Alarussi, A.S. and Alhaderi, S.M. (2018) Factors Affecting Profitability in Malaysia. Journal of Economic Studies, 45, 442-458. https://doi.org/10.1108/JES-05-2017-0124 
[2] Edwards, J.B. (2016) Modern Gross Profit Analysis. The Journal of Corporate Accounting and Finance, 27, 45-55. https://doi.org/10.1002/jcaf.22160

[3] Chiu, P.-C. and Haight, T. (2014) Gross Profit Surprises and Future Stock Returns.

[4] Cepeda, J.A. (2002) System and Method for Allocating Operating Expenses. Patent Application Publication.

[5] Said, R.M. and Tumin, M.H. (2011) Performance and Financial Ratios of Commercial Banks in Malaysia and China. International Review of Business Research Papers, 7, 157-169.

[6] Dermawan, E.S. and Indrajathi, M.D. (2017) The Quality of Operating Profit and Other Comprehensive Income; Evidence from Indonesia Stock Exchange. International Journal of Economic Perspectives, 11, 1545-1557.

[7] Bodla, B.S. and Verma, R. (2006) Determinants of Profitability of Banks in India: A Multivariate Analysis.

[8] Pritchett, T. (1973) Operating Expenses of Life Insurers, 1961-70: Implications for Economies of Size. The Journal of Risk and Insurance, 40, 157-165. https://doi.org/10.2307/252108

[9] Collins, J.H. and Shackelford, D. (1997) Global Organizations and Taxes: An Analysis of the Dividend, Interest, Royalty, and Management Fee Payments between U.S. Multinationals' Foreign Affiliates. Journal of Accounting and Economics, 24, 151-173. https://doi.org/10.1016/S0165-4101(98)00004-4

[10] Thuronyi, V. (1988) Tax Expenditures: A Reassessment. Duke Law Journal, 1977, 1155-1206. https://doi.org/10.2307/1372533

[11] Wikimedia Foundation (2020) Interest Expense. https://en.wikipedia.org/wiki/Interest expense

[12] Kagan, J. (2020) Interest Expense. Investopedia. https://www.investopedia.com/terms/i/interestexpense.asp\#: :text=Interest\%20exp ense $\% 20$ is\%20a\%20non,principal\%20amount\%20of\%20the\%20debt

[13] Prakash, P. and Sunder, S. (1979) The Case against Separation of Current Operating Profit and Holding Gain. The Accounting Review, 54, 1-22.

[14] Cao, W.-J., Liu, W.-S., Koh, C.G. and Smith, I.F. (2020) Optimizing the Operating Profit of Young Highways Using Updated Bridge Structural Capacity. Civil Structural Health Montoring, 10, 219-234. https://doi.org/10.1007/s13349-020-00379-3

[15] Wikimedia Foundation (2020) Net Income. https://en.wikipedia.org/wiki/Net income

[16] Glew (n.d.) What Is Net Profit and How to Calculate It? Glew. https://glew.io/tip/net-profit-calculate

[17] Myers, J.H. (1959) The Critical Event and Recognition of Net Profit. The Accounting Review, 34, 528-532.

[18] Averkamp, H. (2020) Is a Loan's Principal Payment Included on the Income Statement? Accounting Coach.

https://www.accountingcoach.com/blog/principal-payment-financial-statement\#: :t ext=The $\% 20$ principal\%20payment $\% 20$ is $\% 20$ recorded,Notes\%20Payable\%20or\%20 Loans\%20Payable.\&text=The\%20interest $\% 20$ on $\% 20$ the $\% 20$ loan, when $\% 20$ the $\% 20$ in terest $\% 20$ is\%20incurred

[19] Kenton, W. (2020) One-Time Item. Corporate Finance \& Accounting. Investopedia. https://www.investopedia.com/terms/o/one-time-item.asp

[20] Chen, J. (2020) Income Statement. Corporate Finance \& Accounting. Investopedia. 
https://www.investopedia.com/terms/i/incomestatement.asp\#: :text=Also\%20called $\%$ 20other\%20income $\% 2$ C $\% 20$ gains, land $\% 2$ C $\% 20$ or $\% 20 \mathrm{a} \% 20$ subsidiary $\% 20$ company

[21] Boyte-White, C. (2020) Revenue vs. Income: What's the Difference? Corporate Finance \& Accounting. Investopedia.

https://www.investopedia.com/ask/answers/122214/what-difference-between-reven ue-and-income.asp\#: :text=Revenue $\% 20$ is\%20the $\% 20$ total\%20amount,company's \%20total\%20earnings\%20or\%20profit

[22] Schmidt, M. (2020) Profitability Metrics and Profit Margins. Business Encyclopedia. https://www.business-case-analysis.com/profitability.html 